ISSN 1392-7450, e. ISSN 2335-8785

http://dx.doi.org/10.7220/1392-7450.48(76).5

SOTER 2013.48(76)

\section{Svetoslava TONCHEVA}

Jenos Friedricho Schillerio universitetas

\title{
Anthroposophy as Religious Syncretism
}

Straipsnyje nagrinëjama Rudolfo Steinerio antroposofija - naujasis religinis judèjimas, turèjęs didelę itaką postmoderniajai Europai. Antroposofija analizuojama kaip sinkretinè dvasiné sistema, susiformavusi Europos kultūros kontekste (ypač vokiečių kultūros erdvèje), šiuolaikinio mokslo vystymosi laikotarpiu. Atsižvelgiant ị ši kontekstą ir tai, kad nuo XIX a. Europai didelę ịtaką dare Rytų dvasingumas, straipsnyje bandoma apibrèžti antroposofinès pasaulezžiūros aspektus, susijusius su istorine pasaulio ir žmogaus raida.

The article is dedicated to one of the most significant for postmodern Europe new spiritual movements - the anthroposophy of Rudolf Steiner. It examines this particular phenomenon as a syncretic spiritual system, which developed within the European cultural context (the German cultural space) in a specific for the development of the modern science period. Considering this context and the influence of the Eastern spirituality, which penetrates into Europe during the 19th century, the article attempts to outline the functional aspects of the anthroposophical worldview on the example of its ideas related to the historical development of the world and the human being.

\section{Introduction}

The dramatic social, cultural and geo-political changes, which Europe (and the world) underwent during the $19^{\text {th }}-20^{\text {th }}$ century, had a broad impact, including in the religious sphere (mainly in relation to the process of secularization). One result of these transformations is the emergence of new religious/spiritual movements (NRMs, new spirituality), which appear to change the world religious sphere. The questions and problems related to them are an object of multi-disciplinary research - psychology, sociology, theology, history of religions, anthropology, ethnology, folklore studies, etc.

In science, by the term new religious movements we understand "various organizations $<\ldots>$ that offer an answer to fundamental questions of religious, spiritual or philosophical nature"1. Despite the broadly discussed thesis about the considerably decreased significance of religion, the number of new religious movements during the $19^{\text {th }}-20^{\text {th }}$ century is impressive. This phenomenon is mainly due to the "opening up" of the world, migrations and the arrival of many foreign (to local traditions) religious-philosophical systems. One such movement, influenced by the eastern spiritual systems but founded on native (European) soil and consistent with the cultural, social and national requirements of the epoch and the environment in which they emerge is anthroposophy of Rudolf Steiner.

Created in the early $20^{\text {th }}$ century in the German cultural and linguistic sphere (Germany, Switzerland, and Austria) anthroposophy stands out amongst the hundreds and thousands of new spiritual movements, the majority of which existed only briefly, for several reasons: the movement still preserves its vitality today, a fact supported by the number 
of its followers and its broad areal of diffusion - over 60000 around the world; the movement has an important significance in the social sphere in the form of the so-called Waldorf Schools and Kindergartens, the specific "anthroposophical" medicine, bio-dynamic agriculture, pharmacy, banking, Christian Communities (Christengemeinschaft), art (theatre and architecture), and political ideas (Steiner's ideas about the Triple structure of the social organism). The significance of the movement can be judged by the mass celebrations that took place in 2011, not only in Austria, Germany and Switzerland, but around the world, on the occasion of the $150^{\text {th }}$ anniversary of R. Steiner.

The present article is aiming to examine the anthroposophical worldview as religious syncretism, i.e. as religious/spiritual bricolage (in Lévi-Strauss' terminology ${ }^{2}$ ) of Eastern and European concepts and ideas, and its functions, but in the context of the cultural and historical discourse of the particular period.

\section{Anthroposophy and the Zeitgeist ${ }^{3}$}

The $19^{\text {th }}$ century allows humanity to look at the history of the world through the prism of the scientific achievements of that period - in central place here is Charles Darwin's work On the Origin of Species by Means of Natural Selection, or The Preservation of Favoured Races in the Struggle for Life. ${ }^{4}$ This "view" is based on a couple of key factors: the "opening up" of the world (as a result of the great geographical discoveries) and colonization, which together lead to the discovery and study of unknown tribes and peoples (this is the birth of a new science - anthropology). The attempts at organizing Man's development into a united scheme are, on the one hand, scientific - classification according to the level of their evolutionary development (natural evolutionism) and, on the other hand, spiritual (the so-called spiritual history, Geistgeschichte - a look at the spiritual development of Man through the ages). Enthusiastically adopted by materialists, the scientific discoveries pose a great challenge to both idealists and the religious, spiritual Man - causing doubt in the existence of a "Divine Plan". In other words, they postulate the lack of an ultimate meaning: the unconditional "fulfilment" of God's plan ${ }^{5}$. The discoveries of archaeology clearly prove the existence of a past that differs from the Biblical one. In what way can such facts pertain to the sacral history shared by religious Man? This is a fundamental problem, which is a prerequisite for the widely debated idea of this period that is the necessity of a connection between religion and science ${ }^{6}$.

Christianity is no longer the only religion of revelation in the European world - Europe (and the USA) is flooded by various eastern religions and systems, by new prophets and revelations. Moreover, in the process of secularization, religions are declared an obstacle to scientific progress. The concept, accepted ultimately by the intellectuals in Europe, is that philosophy manages to prove the inconsistency of the idea of God and the soul as an independent spiritual substance.

In this context, in the middle of the $19^{\text {th }}$ century, the foundations for comparative religious science are being laid (first and foremost Auguste Comte, as well as Ludwig Büchner, for whom the spiritual is a combination of brain functions, and life emerged by means of spontaneous generation). A fundamental work in this area is Max Müller's 
Comparative Mythology: An Essay ${ }^{7}$ (original from 1856). The new discipline named history of religions continues to develop with the work of Eduard Taylor and his theory of animism ${ }^{8}$. This approach, reflecting Darwin's evolutionary theory, quickly becomes popular. One of the explanations for the popularity of Darwinism in all spheres of science is its optimism - understanding and mastering matter, Man will be able to master it, and as a result, achieve happiness, fortune and power through his own efforts in the eternal process of evolution.

The triumph of materialism defines two of the main characteristics of the new spiritual movements. On the one hand, they appear in order to fill the mixture of "intellectual and spiritual vacuum", a result of the collapse of historical Christianity; and on the other hand - they are also optimistic, offering an eternal spiritual evolution of Man in which he can achieve higher and higher levels of existence and development. In this way the new religious movements translate the world cultural processes by means of a "re-spiritualized, occult macro-drama of beginning and end in the Divine"10.

This quest for the beginning of everything, or to use M. Eliade's apt phrase "obsession with the initial", as well as the peculiar positivism, characterize the spirit of that period (the so-called Zeitgeist). Not surprisingly, modern irrationalism also emerges at the same time - i.e. the religious (spiritual) answer to the questions of the modern man.

This is namely the context, in which anthroposophy is being born. Just as initial comment, it could be summarized as a combination of German Idealism - that of G. W. Hegel, J. G. Fichte, F. Schelling, Goethe's worldview, the eastern teachings that penetrated into the west, as well as the achievements of evolutionism (primarily Darwinism).

\section{Anthroposophy as spiritual science}

The teaching (philosophy, spiritual science), created by R. Steiner and named anthroposophy (Anthroposophie) has some specifics that should be outlined when trying to analyse it. Etymologically anthroposophy stems from the ancient Greek - äv $\theta \rho \omega \pi$ oc (ánthropos) man and бopía (sophía) - wisdom. As synonyms of anthroposophy the terms "spiritual science" (Geisteswissenschaft) and "secret science" (Geheimwissenschaft) are sometimes used. Steiner's anthroposophy offers a scientific investigation of the spiritual world aided by Man's own spiritual powers, which need to be permanently developed. It is a way of knowledge that can connect the spiritual within Man to the spiritual in the universe. In other words, it is a contemporary way of initiation into the divine. According to anthroposophists, it is the sole path for contemporary civilization to avert decline and degeneration ${ }^{11}$.

The term "secret science", used by Steiner for anthroposophy (as well as by other occultists before him in connection with other teachings), places an emphasis on the knowledge and investigation of that which remains unrevealed in natural phenomena when they are perceived by Man through means of his senses and brain - i.e. through the material. Spiritual science, in his opinion, explores the hidden (spiritual) essence of natural phenomena by means of supernatural knowledge. Secret science focuses on the human soul, as well as on the idea of releasing the natural-scientific method from its 
"limited application on the sensory facts". The objects of research in spiritual science are "non-sensory phenomena", and the task - the development of Man's spiritual powers, acquired through an exploration of nature. The enquiring anthroposophist is defined as a spiritual-scientific explorer who brings to the fore his spiritual activity. And while the natural-scientific approach is connected to an application of evidence, in the spiritualscientific approach, spiritual activity takes place in the very search for facts itself.

Anthroposophy is based on two main ideas:

1. Behind the visible world lies an invisible one that for the moment remains hidden.

2. If Man develops the skills endowed within him, he can penetrate into this world.

\section{Anthroposophy as religious syncretism}

R. Steiner's esoteric interests are related, at a first place, to the Theosophical Society and the ideas of Helena Blavatsky (traveler, philosopher, writer, occultist and spiritualist) who founds the Society in New York in 1875 together with lieutenant colonel H. S. Olcott and the lawyer W. Q. Judge. The society aims: to form a nucleus of the Universal Brotherhood of Humanity, without distinction of race, creed, sex, caste, or color; to encourage the study of Comparative Religion, Philosophy, and Science; to investigate the unexplained laws of Nature and the powers latent in man. H. Blavatsky is an author of "Isis Unveiled"12 and "The Secret Doctrine"13.

R. Steiner's connections with the theosophists continue for 12 years. He delivers lectures in front of a growing audience. He is elected to be a secretary of the German section of the Theosophical Society during its foundation in Berlin in the presence of Annie Besant ${ }^{14}$ (one of the influential figures in the Theosophical Society), where he develops his own ideas (which later become a basis for his anthroposophy).

The influence of theosophy, in this relation, which is also visible in many of R. Steiner's ideas, is beyond all doubt. As an example we could point out the source of Steiner's knowledge, which he refers to as the so-called "Akasha Chronicle"15 (known also as "The Akashic Records" or "Book of Life"), on which the theosophical tradition still relies. The "Akasha Chronicle" is considered to be a spiritual record of all world events and their spiritual essence. According to Steiner, the "Akashic Records" (about everything that was, is and will be) will be revealed to humanity gradually and depending on the spiritual development of Man.

It is also expressed not only in Steiner's spiritual chronology - the cosmic cycles of evolution, but also in the ideas of the Bodhisattvas (spiritual teachers of humanity), as well as those of karma and reincarnation, involution and evolution, "secret science", etc.

On the other hand, central point for anthroposophy remains the Christianity, which is the basic difference from theosophy. This is very clearly expressed in the aim, which anthroposophy claims to be able to prepare followers for - the new appearance of Christ in the 20th century. Second appearance of Christ will be etheric (i.e. non-material), but not physical. The influence of Christianity is obvious in many of Steiner's ideas. Here, as an example of those, as well as of the syncretism of the anthroposophycal spiritual worldview, we will present some basic ideas, concerning the history of the world in Steiner. 


\section{The Historical Development of the World and Man}

In the context of the so-called Zeitgeist, a fundamental concept in the anthroposophy of R. Steiner is the presentation of the world's evolution first and foremost as a spiritual process. He dedicated a huge part of his lectures, book and articles to this problem and the attempt to answer the current questions about the connection between material and spiritual. To a large extent Steiner's works, influenced by Goethe's ideas about the path between spirit and matter, are a response to the reaction against the very popular books of the famous zoologist and philosopher E. Haeckel ${ }^{16}$. Of particular importance is his book Natürliche Schöpfungsgeschichte ${ }^{17}$, translated into many languages and reprinted 20 times. Evolutionary theory, in his opinion, turns theological explanations about the origins of the world and life into archaisms. Attempting to reconcile science and religion, Steiner accepts the theory of evolution, but prefers to apply it by interpreting it as a process of, a result of, and a reflection of spiritual evolution.

At the centre of Steiner's macro-history is Jesus Christ, who remains neglected in Theosophy, offering a history of the world that is very similar to the anthroposophical ${ }^{18}$. Christ represents the boundary between the processes of involution (the exit of the soul from God and the process of descent), and the beginning of evolution (the return to the spiritual). The earth in the anthroposophical evolutionary concept (dealing with esoteric terms and concepts: Indian, Kabbalistic, Christian, Rosicrucian etc.: compare reincarnation, angels, archangels, abnormal angels, spirits, spirits of the peoples, etc.) passes through three periods of physical embodiment, separated by periods of pure spiritual existence:

Man develops his current form during the fourth material incarnation of Earth. During the previous three periods, three bodies are developed, the embryo of modern Man. The embodiments of the Earth are described with the names of planets from the Solar system, but with the qualification that they only symbolize a certain phase and are not their equivalent. In this way, Earth passes through the states of "old" Saturn, Sun and Moon in order to reach its present form. During the "old" Saturn phase, Man's physical body is developed in an initial form; during the Sun phase, the etheric body; during the Moon phase, the astral; and during the Earth phase, the "I". Various spiritual creatures are connected with the development of Man and his bodies: Spirits of Wisdom (in the Christian tradition - Kiriotetes or Dominions), Spirits of Will (Thrones), Spirits of Motion (Dinamis or Forces), Spirits of Form (Authorities), Spirits of Individuality/Personality (Arhai, Beginnings), which give the rudiments of the I; Spirits of Fire (Archangels), Spirits of Love (Seraphim), Spirits of Harmony (Cherubs) and Sons of Life (Angels). During the period of Saturn only a hint of Man exists, which is also the seed of the Man-Spirit. Steiner relates the state of Saturn to the sensory elements of heat, light, taste, sound and smell.

It is obvious, that Steiner's history of the world is an analogue to the natural history of Charles Darwin in a "spiritual context". Its chronology, space and axiology are influenced by (borrowed from) the theosophical (dominated by Indian religious teachings), esoteric and Christian traditions. 
A key point that affects the development of mankind in the present age is that it takes its spiritual guidance from the Archangel Michael - an event that Steiner attributes to $1879^{19}$. The historical development of the period is guided by the so-called Time Spirits (named also Archangels), who are seven ${ }^{20}$ in number. The role of Archangel Michael in the evolution of Man is related to the development of the human mind - those who follow him, will overcome the dragon (a symbol of materialism and the materialistic view of evolution).

Steiner develops the concept about the evolution of peoples, named also spiritual ethnology (spirituelle Ethnologie ${ }^{21}$ ). According to it, apart from time and space, invisible beings called archangels, also provide patronage to the peoples of the world, defining their character and existence. The connection of these "National Spirits" to the ideas of German Romanticism and ethnography is obvious - the spirit of the people, a source of folklore (J. Herder ${ }^{22}$, who influences Goethe and the Brothers Grimm). Steiner connects those spirits with his spiritual history - they are the "aura" of the people, proving their main characteristics ${ }^{23}$. In connection with the peoples, "spiritual ethnology" also examines the question of races, which opens up anthroposophy to accusations of racism. In Steiner's view, the races have been inherent to humanity since the Lemurian epoch, and will disappear in the future sixth epoch. They are connected with particular regions of the world, and the activity of Earth's powers or properties (the African lineage is connected with qualities inherent in early childhood, the Asian - with youth, the American - with the period after the middle third of the human life, and the European-with adulthood). However, Man is reincarnated/reborn, and in this way passes through the various races in this way "no one is harmed" 24 .

In this context anthroposophy is an interesting attempt at representing esotericism and occultism as a science, through connecting scientific methodology to the ideas of the spiritual.

\section{Conclusions}

Having examined Steiner's ideas about the development of the world in the context of the Zeitgeist and the Eastern and the Western key points in his spiritual system, we could make some final conclusions on the basis of the particular example.

It is obvious that Steiner's history of the world is an answer to the theory of evolution, an attempt to translate evolutionism into the language of spirituality. In synchrony with the era in which he works, Steiner relies on scientific knowledge in the field of linguistics (historical and comparative linguistics, which subsequently underwent significant corrections), archaeology, anthropology, history, science, philosophy and astronomy. He bravely struggles with world mythology - Indian, Persian, Greek and ancient Egyptian, organizing them, similar to the theosophists, into a "scientific" system that explains the world. On the other hand, he is well acquainted with the esoteric tradition and contemporary transformations in the spiritual/religious sphere. The indisputable creative contribution of Steiner to this wave is the inclusion of Christian mythology in the spiritual 
system and favouritism towards the figure of Christ, with which begins the "evolutionary spiritual path of humanity". This is a powerful idea, reconciling the believing and the knowing man of the $19^{\text {th }}-20^{\text {th }}$ century, offering him a new spiritual view of the world and life by the means of specific religious/spiritual syncretism.

\section{REFERENCES}

1 Barker E. New Religious Movements: A Practical Introduction. London: Bernan Press. 1990.

2 See more in Lévi-Strauss C. La pensée sauvage. Paris: Plon. 1962.

3 The spirit of the time.

4 Darwin C. The Origine of Species by Means of Natural Selection, or the Preservation of Favoured Races in the Struggle for Life. London: John Murray. 1859.

5 Trompf G. W. Macrohistory in Blavatsky, Steiner and Guénon // Gnostica 2. Western Esotericism and the Science of Religion / eds. G. W. Trompf, U. Hanegraaff a.o. Leuven: Peeters Publishers. 1998. P. 271.

$6 \quad$ Idea formulated by H. Spencer (in 1862).

7 Müller M. Comparative Mythology: An Essay. Kessinger Publishing. 2003.

8 Tylor E. B. Primitive Culture: Researches into the Development of Mythology, Philosophy, Religion, Languages, Art and Customs. London: John Murray. 1871.

9 Trompf. Op. cit. P. 273.

10 Ibid. P. 274.

11 Прокобиев С. О. Рудолф Щайнер и Крайъгълните мистерии на нашето време. Стара Загора: Антропософско издателство “Даскалов”. 2009. Р. 16.

12 Blavatsky H. Isis Unveiled. London: Theosophical Publishing House. 1877.

13 Blavatsky H. The Secret Doctrine: The Synthesis of Science, Religion, and Philosophy. London: The Theosophical Publishing Company. 1888.

14 British journalist who takes the lead of the Theosophical Society after the death of Olcott (already by the establishment of the Theosophical Society he is a president and H. Blavatsky - a secretary).

15 "Akasha" - is a Sanskrit word meaning "air", "ether", "initial substance", and according to Hinduism, that of which everything, the whole universe consists; it is one of the five elements, whose characteristic is sound. The term is introduced by theosophy (which borrows it from the Hindu philosophy of Samkhya) where it is used in a sense of mystical knowledge (about Man and universe), encoded in invisible script. According to R. Steiner, those, initiated in the understanding of this invisible script, can look into a much more distant past than the one which official history describes (Steiner R. Aus der Akasha-Chronik (1904-1908). 6. Aufl. Dornah: Rudolf Steiner Verlag. 1986).

16 E. Haeckel is an Austrian zoologist and philosopher who introduces the term "ecology" into science and formulates the so-called "biogenetic law", according to which phylogenesis repeats ontogenesis. He develops further the evolutionism of Darwin, defining the species monkey (the term "pithecanthropus" is also introduced by him), from which originates man.

17 Haeckel E. Natürliche Schöpfungsgeschichte. Berlin: Verlag Georg Reimer. 1868.

18 Trompf. Op. cit. P. 274.

19 For the mission of Archangel Michael see Steiner R. Die Sendung Michaels. Die Offenbarung der eigentlichen Geheimnisse des Menschenwesens (1919). 4. Aufl. Dornah: Rudolf Steiner Verlag. 1994.

20 There are seven archangels in Christianity - Gabriel, Michael, Raphael, Uriel, Raguel, Remiel and Saraqael. Michael has a leading role as a keeper of Heaven and the law of God. In the Christian tradition, his function is to guide the forces of Heaven against the forces of Darkness, and symbolizes 
a model of the virtues of the spiritual warrior and the inner battle. He carries souls to the other world, and is frequently portrayed as a dragon slayer. According to the anthroposophic tradition his guidance will continue for about 320 years.

21 Steiner R. Volksengel. Ein Grundkurs in spiritueller Ethnologie. Bad Liebenzell: Archiati Verlag. 2008.

22 The so-called father of "cultural nationalism".

23 Щайнер Р. Отделните души на народите и тяхната мисия във връзка със северно-германската митология. Стара Загора: Димо Даскалов. 2000. Р. 44.

24 Ibid. P. 97.

\section{LITERATURE AND SOURCES}

1. Barker E. New Religious Movements: A Practical Introduction. London: Bernan Press. 1990.

2. Blavatsky H. Isis Unveiled. London: Theosophical Publishing House. 1877.

3. Blavatsky $H$. The Secret Doctrine: The Synthesis of Science, Religion, and Philosophy. London: The Theosophical Publishing Company. 1888.

4. Darwin C. The Origine of Species by Means of Natural Selection, or the Preservation of Favoured Races in the Struggle for Life. London: John Murray. 1859.

5. Haeckel E. Natürliche Schöpfungsgeschichte. Berlin: Verlag Georg Reimer. 1868.

6. Lévi-Strauss C. La pensée sauvage. Paris: Plon. 1962.

7. Müller M. Comparative Mythology: An Essay. Kessinger Publishing. 2003.

8. Steiner R. Aus der Akasha-Chronik (1904-1908). 6. Aufl. Dornah: Rudolf Steiner Verlag. 1986.

9. Steiner R. Die Sendung Michaels. Die Offenbarung der eigentlichen Geheimnisse des Menschenwesens (1919). 4. Aufl. Dornah: Rudolf Steiner Verlag. 1994.

10. Steiner R. Volksengel. Ein Grundkurs in spiritueller Ethnologie. Bad Liebenzell: Archiati Verlag. 2008.

11. Tylor E. B. Primitive Culture: Researches into the Development of Mythology, Philosophy, Religion, Languages, Art and Customs. London: John Murray. 1871.

12. Trompf G. W. Macrohistory in Blavatsky, Steiner and Guénon // Gnostica 2. Western Esotericism and the Science of Religion / eds. G. W. Trompf, U. Hanegraaff a.o. Leuven: Peeters Publishers. 1998. P. 267-296.

13. Прокофиев С. О. Рудолф Щайнер и Крайъгълните мистерии на нашето време. Стара Загора: Антропософско издателство “Даскалов”. 2009.

14. Щайнер Р. Отделните души на народите и тяхната мисия във връзка със северно-германската митология. Стара Загора: Димо Даскалов. 2000.

Gauta: 20131004

Parengta spaudai: 20131206

\section{Svetoslava TONCHEVA}

\section{ANTROPOSOFIJA KAIP RELIGINIS SINKRETIZMAS}

\section{S u m m a r y}

Straipsnyje nagrinėjamas naujasis dvasingumas ir jo apraiškos šiuolaikiniame pasaulyje, aptariamas konkretus dvasinis judejjimas - antroposofija, išplètota Rudolfo Steinerio vokiečių kultūros erdvėje XIX a. pirmojoje pusèje. Daug dèmesio skiriama antroposofinei pasaulěžiūrai kaip religiniam sinkretizmui, t. y. religiniam (dvasiniam) perkūrimui. 
Taigi antroposofija visų pirma suvokiama kaip tam tikrų istorinių aplinkybių arba to laikmečio „dvasios“ rezultatas, šis reiškinys apibūdinamas vokiečių terminu Zeitgeist. XIX a. - tai šiuolaikinio mokslo vystymosi, pasaulio „atsivėrimo“ ir kolonizacijos laikotarpis: atrastos ir tyrinejamos nežinomos gentys ir tautos, susiformavo nauja mokslo šaka - antropologija. Moksliniai atradimai paskatino abejones dèl „dieviškojo plano“ egzistavimo, būtinybès ieškoti mokslo ir religijos sąsajų. Šiame kultūriniame ir istoriniame diskurse nagrinejjama antroposofija - tai bandymas suderinti tikèjimą ir šiuolaikinio mokslo atradimus, antroposofija pristatoma kaip dvasinis „mokslas“.

Kita vertus, šis judèjimas susiformavo tam tikroje kultūrinëje erdvèje, didžiausią įtaką turèjo vokiečių dvasinè ir filosofinè tradicija. Antroposofai rèmèsi vokiečiu idealizmu (G. W. Hegelio, J. G. Fichte’s, F. Schellingo idèjomis) ir net J. W. Goethe’s pasauležiuura (taip pat ir mokslinėmis jo idèjomis). Be to, R. Steinerio idèjos yra tiesiogiai susijusios su krikščionybe, tai antroposofinès pasaulěžiūros pagrindas. Antroposofai kalba apie naujajj Kristaus atejimą XX a.

R. Steineriui itakos turèjo Jelenos Petrovnos Blavatskajos darbai, jo ezoteriniai interesai neatsiejami nuo Teosofų draugijos. Teosofijos ịtaką liudija R. Steinerio idejos, tokios kaip R. Steinerio žinių šaltinis (vadinamosios „Akasha kronikos“), dvasinè chronologija - evoliucijos kosminiai ciklai, Bodhisatvos idèjos (apie žmonijos dvasinius mokytojus), taip pat karma ir reinkarnacija, involiucija ir evoliucija, „slaptasis mokslas“ ir kt. R. Steinerio idejjos, susijusios su istorine pasaulio ir žmogaus raida, atspindi teosofinę chronologiją, bet skiriasi tuo, kad kalbama apie Kristų ir ypatingą jo misiją.

R. Steinerio antroposofija yra atsakas ị evoliucijos teoriją, bandymas išversti evoliucionizmą ị dvasingumo kalbą. Greta Zeitgeist R. Steineris remiasi lingvistikos, archeologijos, antropologijos, istorijos, mokslo, filosofijos ir astronomijos žiniomis. Jau nusistovejjusių dvasinių sistemų (krikščionybès) perkūrimas, ị naują dvasinę pasaulèžiūrą integruota pasaulio mitologija ir ezoterinè tradicija leidžia (bent jau antroposofijos sekejjų nuomone) suderinti tikintį ir žinantį XIX-XX a. žmogų.

PAGRINDINIAI ŽODŽIAI: naujieji dvasiniai (religiniai) judejjimai, religinis sinkretizmas, antropologija, antroposofija, evoliucija, perkūrimas.

KEY WORDS: new spiritual/religious movements, religious syncretism, anthropology, anthroposophy, evolution, bricolage.

Svetoslava TONCHEVA - Jenos Friedricho Schillerio universiteto Slavistikos instituto docente, Bulgarijos mokslų akademijos Etnologijos ir folkloro instituto mokslinè bendradarbė. El. pastas svetahet@abv.bg.

Svetoslava TONCHEVA - Assistant Professor in Friedrich-Schiller-Universität Jena, Department of Slavic Studies, as well as associate in the Institute of Ethnology and Folklore Studies in Bulgarian Academy of Sciences. E-mail: svetahet@abv.bg. 